\title{
SARS-CoV-2 signaling pathway map: A functional landscape of molecular mechanisms in COVID-19
}

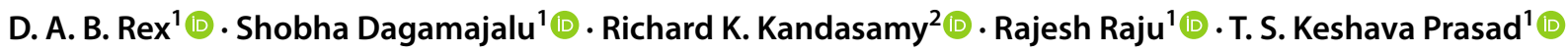

Received: 7 June 2021 / Accepted: 16 June 2021 / Published online: 28 June 2021

(c) The International CCN Society 2021

\begin{abstract}
Coronavirus disease (COVID-19) is caused by severe acute respiratory syndrome coronavirus 2 (SARS-CoV-2). COVID-19 has been declared a pandemic by WHO. The clinical manifestation and disease progression in COVID-19 patients varies from minimal symptoms to severe respiratory issues with multiple organ failure. Understanding the mechanism of SARSCoV-2 interaction with host cells will provide key insights into the effective molecular targets for the development of novel therapeutics. Recent studies have identified virus-mediated phosphorylation or activation of some major signaling pathways, such as ERK1/2, JNK, p38, PI3K/AKT and NF-KB signaling, that potentially elicit the cytokine storm that serves as a major cause of tissue injuries. Several studies highlight the aggressive inflammatory response particularly 'cytokine storm' in SARS-CoV-2 patients. A depiction of host molecular dynamics triggered by SARS-CoV-2 in the form of a network of signaling molecules will be helpful for COVID-19 research. Therefore, we developed the signaling pathway map of SARS-CoV-2 infection using data mined from the recently published literature. This integrated signaling pathway map of SARS-CoV-2 consists of 326 proteins and 73 reactions. These include information pertaining to 1,629 molecular association events, 30 enzyme catalysis events, 43 activation/inhibition events, and 8,531 gene regulation events. The pathway map is publicly available through WikiPathways: https://www.wikipathways.org/index.php/Pathway:WP5115.
\end{abstract}

Keywords Acute respiratory distress syndrome $\cdot$ RASS pathway $\cdot$ Protein-protein interactions $\cdot$ Inflammation * Interleukins $\cdot$ Cytokine storm

\begin{tabular}{|c|c|c|c|}
\hline \multicolumn{2}{|c|}{ Abbreviations } & PTM & Post-Translational Modifications \\
\hline ARD & Acute Respiratory Distress Syndrome & ACE2 & Angiotensin-Converting Enzyme 2 \\
\hline \multirow[t]{2}{*}{ CRS } & Cytokine Release Syndrome & TMPRSS2 & Transmembrane Serine Protease 2 \\
\hline & & SARS-CoV-2 & $\begin{array}{l}\text { Severe Acute Respiratory Syndrome } \\
\text { Coronavirus } 2\end{array}$ \\
\hline \multirow[t]{2}{*}{$凶$} & majalu & RAAS & Renin-Angiotensin-Aldosterone System \\
\hline & enepoya.edu.in & Ang-II & Angiotensin II \\
\hline \multirow[t]{2}{*}{$\triangle \mathrm{R}$} & & ORF & Open Reading Frame \\
\hline & ail.com & IFN & Interferon \\
\hline$\bowtie \mathrm{T}$ & Prasad & IL & Interleukin \\
\hline
\end{tabular}

keshav@yenepoya.edu.in

D. A. B. Rex

rexprem@yenepoya.edu.in

Richard K. Kandasamy

richard.k.kandasamy@ntnu.no

1 Center for Systems Biology and Molecular Medicine, Yenepoya Research Centre, Yenepoya (Deemed To Be University), Mangalore 575018, India

2 Centre of Molecular Inflammation Research (CEMIR), Department of Clinical and Molecular Medicine (IKOM), Norwegian University of Science and Technology, 7491 Trondheim, Norway

\section{Introduction}

The current outbreak of coronavirus disease (COVID-19), a pandemic caused by a novel severe acute respiratory syndrome (SARS)-like coronavirus (SARS-CoV-2), was first reported from Wuhan, China (Zheng 2020). In a limited time, this epidemic has now spread to 216 countries around the world and 2 international conveyances, infected nearly $35,399,043$ people and causing $1,041,824$ deaths as 
of October 5, 2020 (source: https://www.worldometers.info/ coronavirus/). SARS-CoV-2, a single-stranded RNA virus with a genome size ranges from 26 to 32 kilobases in length, has brought the entire world to a standstill causing unimaginable mortality, morbidity and massive economic damage (Lu et al. 2020). The genome of SARS-CoV-2 expresses both structural and non-structural proteins. The Spike (S) glycoprotein, small envelope (E) protein, membrane (M) glycoprotein and nucleoprotein $(\mathrm{N})$ genes encode structural proteins, whereas non-structural proteins, such as 3-chymotrypsin-like protease, papain-like protease, and RNA-dependent RNA polymerase, are encoded by the open reading frame (ORF) region. ORF region contains 28 SARS-CoV-2 polypeptides: (i) ORF1a/b, two polyproteins encoding 16 non-structural proteins NSP1 to 16; (ii) four structural proteins: S, E, M, and N; (iii) seven accessory proteins: ORF3a, ORF3b, ORF6, ORF7a, ORF7b, ORF8, ORF9b; and (iv), two hypothetical proteins ORF14 and ORF10 (Chan et al. 2020; Y. Huang et al. 2020a, b; Sicari et al. 2020).

A host cell transmembrane enzyme called transmembrane protease serine 2 (TMPRSS2) activates Spike protein/S protein of SARS-CoV-2, which facilitates the attachment of the virus to the host cell receptor called angiotensin-converting enzyme 2 (ACE2) (Bilinska et al. ICU 2020; Djomkam et al. 2020; Hoffmann et al. 2020). The spike protein of SARS-CoV-2 is composed of two subunits, S1 (bulb) for receptor binding and S2 (stalk) for membrane attachment and fusion (Yi et al. 2020). The specific fusion between $\mathrm{S} 1$ and the cognate receptor triggers a drastic conformational change in the $\mathrm{S} 2$ subunit, leading to the fusion between the SARS-CoV-2 virus envelope and the host cell membrane, which releases the nucleocapsid of the virus into the cytoplasm of the host cell (Tung and Limtung 2020). This binding of the virus to the ACE2 receptor downregulates the cellular expression of ACE2 and initiates the invasion of the virus for rapid replication (H. Zhang et al. 2020a, b). ACE2 downregulation leads to an imbalance between the renin-angiotensin system (RAS) and ACE2/angiotensin-(1-7)/MAS after infection may also contribute to multiple organ injury in SARS-CoV-2 patients (Ni et al. 2020). Studying the signaling pathways of SARS-CoV-2 infected cells is one of the fundamental ways to understand the molecular mechanism of cell entry, life cycle, host-cell response and recovery. Also, the characterization of signal transduction pathways induced by SARS-CoV-2 infection may provide key insights into significant molecular targets to develop more efficient diagnosis, tests and antiviral therapeutics and vaccines. We developed a resource of signaling events by SARSCoV-2 infection similar to the previously published pathways including IL-18 (Rex et al. 2020), RANKL/RANK (Raju et al. 2011a), AXL (Dagamajalu et al. 2021b), prolactin (Radhakrishnan et al. 2012), endothelin (Dagamajalu et al. 2021a) and IL-33 (Pinto et al. 2018). To this end, we curated a collection of several relevant research articles, which were recently published, and built a detailed signaling map of SARS-CoV-2 infection. This pathway map comprises of 10,559 molecules undergoing five different categories of molecular reactions. These reactions are assembled through a manual annotation of the scientific literature and depicted as a single pathway map.

The SARS-CoV-2 signaling pathway map is made available through the WikiPathways Database (https://www.wikip athways.org/index.php/Pathway:WP5115).

\section{Methodology}

\section{Literature mining and data curation of SARS-CoV-2 mediated signaling events}

Research articles related to SARS-CoV-2 signaling were fetched from the literature to gather information to build a new pathway map of SARS-CoV-2. Search for articles was carried out in PubMed using the search terms such as ("SARS-CoV-2" OR "COVID-19" OR "Covid-19") AND ("pathway" OR "signaling" OR "signalling"). The abstracts of research articles thus fetched were manually read for screening them. Only those articles, which describe experimentally verified molecular reactions induced by SARSCoV-2 were taken up for in-depth curation. We gathered SARS-CoV-2 pathway information on molecular reactions from both cell line-based in vitro studies and patient-derived clinical sample-based investigations. The signaling reactions were curated and documented based on the previously published NetPath annotation criteria (Kandasamy et al. 2009, 2010). The information on each signaling reaction was annotated and further categorized into the molecular association, catalysis (including post-translational modifications; PTMs), activation/inhibition, translocation and gene regulation events. Each signaling event described in the SARS-CoV-2 pathway are hyperlinked to PubMed identifiers of corresponding articles, from where it was fetched. The signaling reactions activated or modulated by SARS-CoV-2 were arranged topologically from protein-protein interaction to transcriptionally regulated genes following the NetSlim criteria (Raju et al. 2011b).

The curated information from each article was reviewed by an internal reviewer followed by an external reviewer assigned as a Pathway Authority, who is an experienced scientist working in the same field. All corrections and recommendations by Pathway Authority were incorporated into the signaling pathway. Manual curation of signaling events was carried out using a manual curation software called PathVisio (Kutmon et al. 2015). 


\section{Results and discussion}

\section{Development of SARS-CoV-2 signaling pathway network map}

The initial PubMed search fetched 104 articles. Articles published related to the SARS-CoV-2 signaling pathway until September 2020 were thus gathered. These articles were carefully reviewed based on our annotation criteria, which finally selected 28 articles for further curation. The annotated articles yielded a total of 1629 molecular associations, 30 catalysis, 43 activation/inhibition reactions, 8,531 gene regulations and 326 protein expression events, which were induced by the SARS-CoV-2 virus (Supplementary Data 1). These events were incorporated into a representative map of the signaling network (Fig. 1). This SARS-CoV-2 signaling pathway map was submitted to WikiPathways with the ID URL: https://www.wikipathwa ys.org/index.php/Pathway:WP5115. The WikiPathways version of the signaling pathway map can be downloaded in various compatible file formats such as png, pdf and gpml formats.

\section{Summary of SARS-CoV-2 signaling pathway}

SARS-CoV-2 enters the lungs, where the spike glycoprotein of the virus activated by a cellular TMPRSS2, which facilitates the attachment of the virus to ACE2 on cells and allowing the virus to enter the cells (Al-Horani et al. 2020; Faheem et al. 2020; Hoffmann et al. 2020; Vaduganathan et al. 2020; Walls et al. 2020; Yan et al. 2020; H. Zhang et al. 2020a, b). The proteomics study by Stukalov and the team identified the ubiquitination of ACE2 at K702 and K625 in A549-ACE2 cells (Stukalov et al., 2020). In common, NEDD4 modulates the levels of ACE2 ubiquitination, whereas PYR-41 prevented the effects of Ang-II on ACE2, indicating this ubiquitination reaction can present as a novel target for the treatment of cardiovascular complications and pulmonary arterial hypertension (Shen et al. 2020). An increase in ACE2 expression at mRNA and protein levels observed in the early phase of several cardiovascular diseases (Gheblawi et al. 2020; Michaud et al. 2020). A recent report shows that smokers have a higher risk of SARS-CoV-2 infection based on their ACE2 expression profiles, which could contribute to variations in infection susceptibility, disease severity, and treatment outcome (Cai et al. 2020).

Several reports have described the interaction of SARSCoV-2 proteins with cell-type-specific protein complexes contributing to various biological functions (Astuti and
Ysrafil 2020). The viral proteins interact with vesicular sorting and fusion machinery and could impact a plethora of membrane proteins, such as receptors involved in thrombosis, type I/III interferons (IFNs), NF-kB and Interleukin 6 (IL-6) signaling (Blanco-Melo et al. 2020). open reading frame $3 \mathrm{a}(\mathrm{ORF} 3 \mathrm{a})$ is a SARS-CoV-2 viral protein showing a pro-apoptotic activity and interacts with the The conserved vacuolar/lysosomal homotypic fusion and vacuole protein sorting (HOPS) complex, which is essential for autophagosome-lysosome fusion and its key components. Similarly, NSP6, a viral protein, is known to be involved in the regulation of lipid metabolism and autophagy. ORF3 and NSP6 interact with host autophagy receptors: (Sequestosome 1 (SQSTM1), Gamma-aminobutyric acid receptor-associated protein-like 2 (GABARAPL2), Next to BRCA1 gene 1 protein (NBR1), CALCOCO2, MAP1LC3B and TAX1BP1) leads to autophagosome / late endosome, however, the mechanism remains unknown. Open reading frame $8(\mathrm{ORF} 8)$ and open reading frame 3 (ORF3) bind to transforming growth factor beta (TGF $\beta$ )-associated factors and involved in the activation of SMAD1/5. This results in the upregulation of fibrinogens, fibronectin, plasminogen activator inhibitor 1 (SERPINE1) and integrin(s), which modulates cell survival, motility and innate immune responses (Stukalov et al., 2020). Besides, ORF3a interaction induces apoptosis either by the direct activation of caspase- 9 or through the activation of caspase-8, which cleaves BH3-interacting domain death agonist (Bid) to the truncated Bid (tBid) and stimulates activation of caspase-9 (Ren et al. 2020). The SARS-CoV-2 pathway describes the induction and modulation of the many downstream signaling pathways including A mitogen-activated protein kinase (MAPK), Protein kinase $\mathrm{B}$ (Akt), interferon I/III (IFN I/III) and transforming growth factor beta receptor (TGFBR), which forms the core innate immune and pro-inflammatory response. Previous reports have shown that SARS-CoV infection induces the activation of interferon signaling (Frieman and Baric 2008; Totura and Baric 2012). In contrast, SARS-CoV-2 is a weak inducer of IFN-I response in vitro as well as in animal models as compared to other respiratory RNA viruses (Chu et al. 2020; Hadjadj et al. 2020). In the early infection, ORF6 suppresses the interferon-mediated signaling pathway by inhibiting retinoic acid-inducible gene I (RIG-I), interferon induced with helicase $\mathrm{C}$ domain 1 (IFIH1), IFN-stimulated response element (ISRE), IFN-stimulated gene 56 (ISG56) and translocation of IFN regulatory factor 3 (IRF3) and signal transducer and activator of transcription 1 (STAT1), suggesting that SARS-CoV-2 antagonizes IFN production. Whereas in late time points, NSP2 and S proteins exert opposite effects in IFN production. Lei et al., have postulated that the lack of inadequate antiviral response in early-stage may be vital to the SARS-CoV-2 pathogenesis (Lei et al. 2020). 


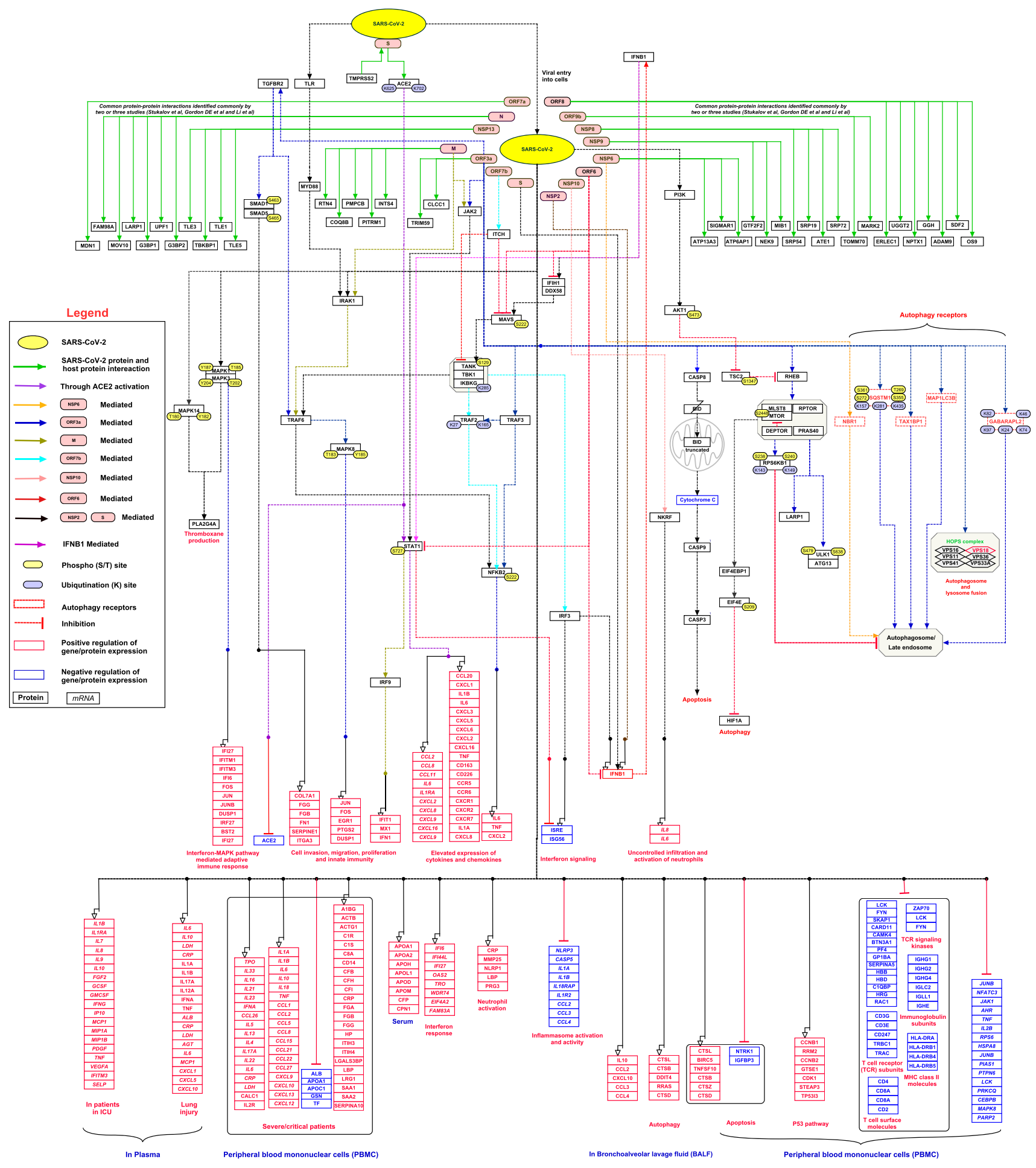

Fig. 1 A schematic representation of the SARS-CoV-2 signaling pathway. The pathway map represents protein-protein interactions and the downstream molecular events regulated by SARS-CoV-2 including molecular association, catalysis, and gene regulation

events. Each event is color-coded as described in the pathway legend. Information on site and residue of post-translational modification is also included in the pathway map 
SARS-CoV-2 mediates the activation of MAPK signaling pathways that trigger alterations in the platelet transcriptome and proteome, and platelet hyperreactivity, which may contribute to COVID-19 pathophysiology (Manne et al. 2020). The SARS-CoV-2 can directly activate NF- $\mathrm{KB}$ in A549cells (Gordon et al. 2020). SARSCoV-2 infection induces the alteration of Akt/mTOR/ HIF-1 signaling in virus-infected Vero-E6 cells, suggesting that targeting of them could be a potential therapy for the management of the disease (Appelberg et al. 2020).

Most of the SARS-CoV-2 infected patients develop mild to moderate symptoms of common viral infections such as fever, cough, and fatigue. In severe cases, they may lead to acute respiratory distress syndrome (ARDS), acute cardiac injury, acute hepatic injury, and acute kidney injury (Ni et al. 2020). We collated a list of proteins and genes elevated in COVID-19 patients from the literature, from early to late-stage based on sample type from different experimental data. Elevated levels of cytokines such as IL-1b, IL-2, IL-6, IL-8, IL-10, monocyte chemoattractant protein-1 (MCP1) and tumor necrosis factor $\alpha$ (TNF- $\alpha$ ) were observed in SARS-CoV-2 infected plasma samples (Chen et al. 2020; C. Huang et al. 2020a, b; Mick et al. 2020; Qiu et al. 2020; J.J. Zhang et al. 2020a, b). Patients admitted in intensive care had significantly higher serum levels of many cytokines and chemokines such as IL-2, IL-7, IL-10, G-CSF, TNF- $\alpha$, and IL-1Ra compared to those who were not in an intensive care unit (ICU). In comparison to healthy controls, they have also showed higher serum levels of IL-6, IL-9, IL-13, GM-CSF, IFN$\gamma$, IL-1 $\beta$, IL-8, and IL-17 (C. Huang et al. 2020a, b). The analysis of peripheral blood mononuclear cells (PBMCs) has revealed that interaction of NSP9 and NSP10 with NKRF (NF-KB repressor), which regulates IL-8/IL-6 mediated chemotaxis of neutrophils and over-exuberant host inflammatory response ( $\mathrm{Li}$ et al. 2020).

SARS-CoV-2 infection induces the release of cytokines and monocyte-associated chemokines in those individuals with a diminished innate immunity causing a more severe presentation of the disease especially in elderly individuals (Costela-Ruiz et al. 2020; Song et al. 2020). This cytokine release syndrome (CRS), also called 'cytokine storm', has been found to be a major cause of tissue damage in the pathophysiology of SARS-CoV-2 (Ye et al. 2020). The proinflammatory cytokines in the plasma have been found to be significantly elevated in patients with severe COVID19 disease (Costela-Ruiz et al. 2020). Several cytokines such as IL-6, IL-1 $\beta$, TNF- $\alpha$ and IFN- $\gamma$ have been frequently reported to be elevated in COVID 19 disease (Del Valle et al. 2020; C. Huang et al. 2020a, b; McGonagle et al. 2020; Tang et al. 2020). IL-6, the most important cytokine in CRS, has been found to be increased in the serum of SARS-CoV-2 patients presenting ARDS (Ronco and Reis 2020; Wu et al. 2020).

\section{Conclusions}

Arrangement of molecular reactions associated with host-pathogen response from the published literature may provide vital clues for the identification of novel therapeutic intervention strategies. We believe that this SARS-CoV-2 signaling pathway map will provide a platform for the biomedical research community to accelerate the research into the complex mechanism of host-pathogen response and disease progression. It will assist in the ongoing SARS-CoV-2 research and roadmap for the prevention, control and treatment of disease.

Supplementary Information The online version contains supplementary material available at https://doi.org/10.1007/s12079-021-00632-4.

Acknowledgements We thank Karnataka Biotechnology and Information Technology Services (KBITS), Government of Karnataka, for the support to the Center for Systems Biology and Molecular Medicine at Yenepoya (Deemed to be University) under the Biotechnology Skill Enhancement Programme in Multiomics Technology (BiSEP GO ITD 02 MDA 2017). RDAB is a recipient of the Senior Research Fellowship (SRF) from the Indian Council of Medical Research (ICMR), Government of India. We also thank Yenepoya for providing a research fellowship to RDAB, before securing an SRF from ICMR. RKK is funded by the Research Council of Norway (FRIMEDBIO) "Young Research Talent" Grant 263168, Centres of Excellence Funding Scheme Project 223255/F50 (to CEMIR), and Onsager fellowship from NTNU.

\section{Declaration}

Conflict of interest The authors report no conflicts of interest.

\section{References}

Al-Horani RA, Kar S, Aliter KF (2020) Potential anti-COVID-19 therapeutics that block the early stage of the viral life cycle: structures, mechanisms, and clinical trials. Int J Mol Sci 21(15):5224

Appelberg S, Gupta S, SvenssonAkusjarvi S, Ambikan AT, Mikaeloff F, Saccon E, Vegvari A, Benfeitas R, Sperk M, Stahlberg M, Krishnan S, Singh K, Penninger JM, Mirazimi A, Neogi U (2020) Dysregulation in Akt/mTOR/HIF-1 signaling identified by proteotranscriptomics of SARS-CoV-2 infected cells. Emerg Microbes Infect 9(1):1748-1760. https://doi.org/10.1080/22221751.2020. 1799723

Astuti I, Ysrafil, (2020) Severe acute respiratory syndrome coronavirus 2 (SARS-CoV-2): an overview of viral structure and host response. Diabetes Metab Syndr 14(4):407-412

Bilinska K, Jakubowska P, Von Bartheld CS, Butowt R (2020) Expression of the SARS-CoV-2 entry proteins, ACE2 and TMPRSS2, in cells of the olfactory epithelium: identification of cell types and trends with age. ACS Chem Neurosci 11(11):1555-1562. https:// doi.org/10.1021/acschemneuro.0c00210

Blanco-Melo D, Nilsson-Payant BE, Liu WC, Uhl S, Hoagland D, Moller R, Jordan TX, Oishi K, Panis M, Sachs D, Wang TT, Schwartz RE, Lim JK, Albrecht RA, tenOever BR (2020) Imbalanced host response to SARS-CoV-2 drives development of COVID-19. Cell 181(5):1036-1045 e9. https://doi.org/10.1016/j. cell.2020.04.026 
Cai G, Bosse Y, Xiao F, Kheradmand F, Amos CI (2020) Tobacco smoking increases the lung gene expression of ACE2, the receptor of SARS-CoV-2. Am J Respir Crit Care Med 201(12):1557-1559. https://doi.org/10.1164/rccm.202003-0693LE

Chan JF, Kok KH, Zhu Z, Chu H, To KK, Yuan S, Yuen KY (2020) Genomic characterization of the 2019 novel human-pathogenic coronavirus isolated from a patient with atypical pneumonia after visiting Wuhan. Emerg Microbes Infect 9(1):221-236. https://doi. org/10.1080/22221751.2020.1719902

Chen G, Wu D, Guo W, Cao Y, Huang D, Wang H, Wang T, Zhang X, Chen H, Yu H, Zhang M, Wu S, Song J, Chen T, Han M, Li S, Luo $X$, Zhao J, Ning Q (2020) Clinical and immunological features of severe and moderate coronavirus disease 2019. J Clin Invest 130(5):2620-2629. https://doi.org/10.1172/JCI137244

Chu H, Chan JF, Wang Y, Yuen TT, Chai Y, Hou Y, Shuai H, Yang D, Hu B, Huang X, Zhang X, Cai JP, Zhou J, Yuan S, Kok KH, To KK, Chan IH, Zhang AJ, Sit KY, Au WK, Yuen KY (2020) Comparative replication and immune activation profiles of SARSCoV-2 and SARS-CoV in human lungs: an Ex vivo study with implications for the pathogenesis of COVID-19. Clin Infect Dis 71(6):1400-1409. https://doi.org/10.1093/cid/ciaa410

Costela-Ruiz VJ, Illescas-Montes R, Puerta-Puerta JM, Ruiz C, Melguizo-Rodriguez L (2020) SARS-CoV-2 infection: the role of cytokines in COVID-19 disease. Cytokine Growth Factor Rev 54:62-75. https://doi.org/10.1016/j.cytogfr.2020.06.001

Dagamajalu S, Rex DAB, Gopalakrishnan L, Karthikkeyan G, Gurtoo S, Modi PK, Mohanty V, Mujeeburahiman M, Soman S, Raju R, Tiwari V, Prasad TSK (2021a) A network map of endothelin mediated signaling pathway. J Cell Commun Signal 15(2):277-282. https://doi.org/10.1007/s12079-020-00581-4

Dagamajalu S, Rex DAB, Palollathil A, Shetty R, Bhat G, Cheung LWT, Prasad TSK (2021b) A pathway map of AXL receptormediated signaling network. J Cell Commun Signal 15(1):143148. https://doi.org/10.1007/s12079-020-00580-5

Del Valle DM, Kim-Schulze S, Huang HH, Beckmann ND, Nirenberg S, Wang B, Lavin Y, Swartz TH, Madduri D, Stock A, Marron TU, Xie H, Patel M, Tuballes K, Van Oekelen O, Rahman A, Kovatch P, Aberg JA, Schadt E, Jagannath S, Mazumdar M, Charney AW, Firpo-Betancourt A, Mendu DR, Jhang J, Reich D, Sigel K, Cordon-Cardo C, Feldmann M, Parekh S, Merad M, Gnjatic S (2020) An inflammatory cytokine signature predicts COVID-19 severity and survival. Nat Med 26(10):1636-1643. https://doi.org/ 10.1038/s41591-020-1051-9

Djomkam ALZ, Olwal CO, Sala TB, Paemka L (2020) Commentary: SARS-CoV-2 cell entry depends on ACE2 and TMPRSS 2 and is blocked by a clinically proven protease inhibitor. Front Oncol 10:1448. https://doi.org/10.3389/fonc.2020.01448

Kumar BK, Sekhar K, Kunjiappan S, Jamalis J, Balana-Fouce R, Tekwani BL, Sankaranarayanan M (2020) Druggable targets of SARS-CoV-2 and treatment opportunities for COVID-19. Bioorg Chem 104:104269

Frieman M, Baric R (2008) Mechanisms of severe acute respiratory syndrome pathogenesis and innate immunomodulation. Microbiol Mol Biol Rev 72(4):672-685. https://doi.org/10.1128/MMBR. 00015-08

Gheblawi M, Wang K, Viveiros A, Nguyen Q, Zhong JC, Turner AJ, Raizada MK, Grant MB, Oudit GY (2020) Angiotensin-converting enzyme 2: SARS-CoV-2 receptor and regulator of the reninangiotensin system: celebrating the 20th anniversary of the discovery of ACE2. Circ Res 126(10):1456-1474. https://doi.org/10. 1161/CIRCRESAHA.120.317015

Gordon DE, Jang GM, Bouhaddou M, Xu J, Obernier K, White KM, O'Meara MJ, Rezelj VV, Guo JZ, Swaney DL, Tummino TA, Huttenhain R, Kaake RM, Richards AL, Tutuncuoglu B, Foussard H, Batra J, Haas K, Modak M, Kim M, Haas P, Polacco BJ, Braberg H, Fabius JM, Eckhardt M, Soucheray M, Bennett MJ,
Cakir M, McGregor MJ, Li Q, Meyer B, Roesch F, Vallet T, Mac Kain A, Miorin L, Moreno E, Naing ZZC, Zhou Y, Peng S, Shi Y, Zhang Z, Shen W, Kirby IT, Melnyk JE, Chorba JS, Lou K, Dai SA, Barrio-Hernandez I, Memon D, Hernandez-Armenta C, Lyu J, Mathy CJP, Perica T, Pilla KB, Ganesan SJ, Saltzberg DJ, Rakesh R, Liu X, Rosenthal SB, Calviello L, Venkataramanan S, Liboy-Lugo J, Lin Y, Huang XP, Liu Y, Wankowicz SA, Bohn M, Safari M, Ugur FS, Koh C, Savar NS, Tran QD, Shengjuler D, Fletcher SJ, O'Neal MC, Cai Y, Chang JCJ, Broadhurst DJ, Klippsten S, Sharp PP, Wenzell NA, Kuzuoglu-Ozturk D, Wang HY, Trenker R, Young JM, Cavero DA, Hiatt J, Roth TL, Rathore U, Subramanian A, Noack J, Hubert M, Stroud RM, Frankel AD, Rosenberg OS, Verba KA, Agard DA, Ott M, Emerman M, Jura $\mathrm{N}$ et al (2020) A SARS-CoV-2 protein interaction map reveals targets for drug repurposing. Nature 583(7816):459-468. https:// doi.org/10.1038/s41586-020-2286-9

Hadjadj J, Yatim N, Barnabei L, Corneau A, Boussier J, Smith N, Pere H, Charbit B, Bondet V, Chenevier-Gobeaux C, Breillat P, Carlier N, Gauzit R, Morbieu C, Pene F, Marin N, Roche N, Szwebel TA, Merkling SH, Treluyer JM, Veyer D, Mouthon L, Blanc C, Tharaux PL, Rozenberg F, Fischer A, Duffy D, Rieux-Laucat F, Kerneis S, Terrier B (2020) Impaired type I interferon activity and inflammatory responses in severe COVID-19 patients. Science 369(6504):718-724. https://doi.org/10.1126/science.abc6027

Hoffmann M, Kleine-Weber H, Schroeder S, Kruger N, Herrler T, Erichsen S, Schiergens TS, Herrler G, Wu NH, Nitsche A, Muller MA, Drosten C, Pohlmann S (2020) SARS-CoV-2 cell entry depends on ACE2 and TMPRSS2 and is blocked by a clinically proven protease inhibitor. Cell 181(2):271-280 e8

Huang C, Wang Y, Li X, Ren L, Zhao J, Hu Y, Zhang L, Fan G, Xu J, Gu X, Cheng Z, Yu T, Xia J, Wei Y, Wu W, Xie X, Yin W, Li H, Liu M, Xiao Y, Gao H, Guo L, Xie J, Wang G, Jiang R, Gao Z, Jin Q, Wang J, Cao B (2020a) Clinical features of patients infected with 2019 novel coronavirus in Wuhan, China. Lancet 395(10223):497-506

Huang Y, Yang C, Xu XF, Xu W, Liu SW (2020b) Structural and functional properties of SARS-CoV-2 spike protein: potential antivirus drug development for COVID-19. Acta Pharmacol Sin 41(9):1141-1149. https://doi.org/10.1038/s41401-020-0485-4

Kandasamy K, Keerthikumar S, Raju R, Keshava Prasad TS, Ramachandra YL, Mohan S, Pandey A (2009) PathBuilder-open source software for annotating and developing pathway resources. Bioinformatics 25(21):2860-2862. https://doi.org/10.1093/bioin formatics/btp453

Kandasamy K, Mohan SS, Raju R, Keerthikumar S, Kumar GS, Venugopal AK, Telikicherla D, Navarro JD, Mathivanan S, Pecquet C, Gollapudi SK, Tattikota SG, Mohan S, Padhukasahasram H, Subbannayya Y, Goel R, Jacob HK, Zhong J, Sekhar R, Nanjappa V, Balakrishnan L, Subbaiah R, Ramachandra YL, Rahiman BA, Prasad TS, Lin JX, Houtman JC, Desiderio S, Renauld JC, Constantinescu SN, Ohara O, Hirano T, Kubo M, Singh S, Khatri P, Draghici S, Bader GD, Sander C, Leonard WJ, Pandey A (2010) NetPath: a public resource of curated signal transduction pathways. Genome Biol 11(1):R3. https://doi.org/10.1186/ gb-2010-11-1-r3

Kutmon M, van Iersel MP, Bohler A, Kelder T, Nunes N, Pico AR, Evelo CT (2015) PathVisio 3: an extendable pathway analysis toolbox. PLoS Comput Biol 11(2):e1004085. https://doi.org/10. 1371/journal.pcbi.1004085

Lei X, Dong X, Ma R, Wang W, Xiao X, Tian Z, Wang C, Wang Y, Li L, Ren L, Guo F, Zhao Z, Zhou Z, Xiang Z, Wang J (2020) Activation and evasion of type I interferon responses by SARSCoV-2. Nat Commun 11(1):3810. https://doi.org/10.1038/ s41467-020-17665-9

Li J, Guo M, Tian X, Wang X, Yang X, Wu P, Liu C, Xiao Z, Qu Y, Yin Y, Wang C, Zhang Y, Zhu Z, Liu Z, Peng C, Zhu T, Liang 
Q (2020) Virus-host interactome and proteomic survey reveal potential virulence factors influencing SARS-CoV-2 Pathogenesis. Med 2(1):99-112.e7. https://doi.org/10.1016/j.medj.2020. 07.002

Lu R, Zhao X, Li J, Niu P, Yang B, Wu H, Wang W, Song H, Huang B, Zhu N, Bi Y, Ma X, Zhan F, Wang L, Hu T, Zhou H, Hu Z, Zhou W, Zhao L, Chen J, Meng Y, Wang J, Lin Y, Yuan J, Xie Z, Ma J, Liu WJ, Wang D, Xu W, Holmes EC, Gao GF, Wu G, Chen W, Shi W, Tan W (2020) Genomic characterisation and epidemiology of 2019 novel coronavirus: implications for virus origins and receptor binding. Lancet 395(10224):565-574

Manne BK, Denorme F, Middleton EA, Portier I, Rowley JW, Stubben C, Petrey AC, Tolley ND, Guo L, Cody M, Weyrich AS, Yost CC, Rondina MT, Campbell RA (2020) Platelet gene expression and function in patients with COVID-19. Blood 136(11):1317-1329. https://doi.org/10.1182/blood.2020007214

McGonagle D, Sharif K, O'Regan A, Bridgewood C (2020) The role of cytokines including interleukin-6 in COVID-19 induced Pneumonia and macrophage activation syndrome-like disease. Autoimmun Rev 19(6):102537

Michaud V, Deodhar M, Arwood M, Al Rihani SB, Dow P, Turgeon J (2020) ACE2 as a therapeutic target for COVID-19; its role in infectious processes and regulation by modulators of the RAAS system. J Clin Med 9(7):2096

Mick E, Kamm J, Pisco AO, Ratnasiri K, Babik JM, Calfee CS, Castaneda G, DeRisi JL, Detweiler AM, Hao S, Kangelaris KN, Kumar GR, Li LM, Mann SA, Neff N, Prasad PA, Serpa PH, Shah SJ, Spottiswoode N, Tan M, Christenson SA, Kistler A, Langelier C (2020) Upper airway gene expression differentiates COVID-19 from other acute respiratory illnesses and reveals suppression of innate immune responses by SARS-CoV-2. Medrxiv. https://doi.org/10.1101/2020.05.18.20105171

Ni W, Yang X, Yang D, Bao J, Li R, Xiao Y, Hou C, Wang H, Liu J, Xu Y, Cao Z, Gao Z (2020) Role of angiotensin-converting enzyme 2 (ACE2) in COVID-19. Crit Care 24(1):422. https:// doi.org/10.1186/s13054-020-03120-0

Pinto SM, Subbannayya Y, Rex DAB, Raju R, Chatterjee O, Advani J, Radhakrishnan A, Keshava Prasad TS, Wani MR, Pandey A (2018) A network map of IL-33 signaling pathway. J Cell Commun Signal 12(3):615-624. https://doi.org/10.1007/ s12079-018-0464-4

Qiu H, Wu J, Hong L, Luo Y, Song Q, Chen D (2020) Clinical and epidemiological features of 36 children with coronavirus disease 2019 (COVID-19) in Zhejiang, China: an observational cohort study. Lancet Infect Dis 20(6):689-696

Radhakrishnan A, Raju R, Tuladhar N, Subbannayya T, Thomas JK, Goel R, Telikicherla D, Palapetta SM, Rahiman BA, Venkatesh DD, Urmila KK, Harsha HC, Mathur PP, Prasad TS, Pandey A, Shemanko C, Chatterjee A (2012) A pathway map of prolactin signaling. J Cell Commun Signal 6(3):169-173. https://doi.org/ 10.1007/s12079-012-0168-0

Raju R, Balakrishnan L, Nanjappa V, Bhattacharjee M, Getnet D, Muthusamy B, Kurian Thomas J, Sharma J, Rahiman BA, Harsha HC, Shankar S, Prasad TS, Mohan SS, Bader GD, Wani MR, Pandey A (2011a) A comprehensive manually curated reaction map of RANKL/RANK-signaling pathway. Database. https://doi.org/10.1093/database/bar021

Raju R, Nanjappa V, Balakrishnan L, Radhakrishnan A, Thomas JK, Sharma J, Tian M, Palapetta SM, Subbannayya T, Sekhar NR, Muthusamy B, Goel R, Subbannayya Y, Telikicherla D, Bhattacharjee M, Pinto SM, Syed N, Srikanth MS, Sathe GJ, Ahmad S, Chavan SN, Kumar GS, Marimuthu A, Prasad TS, Harsha HC, Rahiman BA, Ohara O, Bader GD, Sujatha Mohan S, Schiemann WP, Pandey A (2011b) NetSlim: high-confidence curated signaling maps. Database. https://doi.org/10.1093/datab ase/bar032
Ren Y, Shu T, Wu D, Mu J, Wang C, Huang M, Han Y, Zhang XY, Zhou W, Qiu Y, Zhou X (2020) The ORF3a protein of SARSCoV-2 induces apoptosis in cells. Cell Mol Immunol 17(8):881883. https://doi.org/10.1038/s41423-020-0485-9

Rex DAB, Agarwal N, Prasad TSK, Kandasamy RK, Subbannayya Y, Pinto SM (2020) A comprehensive pathway map of IL-18-mediated signalling. J Cell Commun Signal 14(2):257-266. https:// doi.org/10.1007/s12079-019-00544-4

Ronco C, Reis T (2020) Kidney involvement in COVID-19 and rationale for extracorporeal therapies. Nat Rev Nephrol 16(6):308-310. https://doi.org/10.1038/s41581-020-0284-7

Shen H, Zhang J, Wang C, Jain PP, Xiong M, Shi X, Lei Y, Chen S, Yin Q, Thistlethwaite PA, Wang J, Gong K, Yuan ZY, Yuan JX, Shyy JY (2020) MDM2-mediated ubiquitination of angiotensinconverting enzyme 2 contributes to the development of pulmonary arterial hypertension. Circulation 142(12):1190-1204. https://doi.org/10.1161/CIRCULATIONAHA.120.048191

Sicari D, Chatziioannou A, Koutsandreas T, Sitia R, Chevet E (2020) Role of the early secretory pathway in SARS-CoV-2 infection. J Cell Biol 219(9):e202006005. https://doi.org/10.1083/jcb. 202006005

Song P, Li W, Xie J, Hou Y, You C (2020) Cytokine storm induced by SARS-CoV-2. Clin Chim Acta 509:280-287

Stukalov A, Girault V, Grass V, Karayel O, Bergant V, Urban C, Haas DA, Huang Y, Oubraham L, Wang A, Hamad MS, Piras A, Hansen FM, Tanzer MC, Paron I, Zinzula L, Engleitner T, Reinecke M, Lavacca TM, Ehmann R, Wolfel R, Jores J, Kuster B, Protzer U, Rad R, Ziebuhr J, Thiel V, Scaturro P, Mann M, Pichlmair A (2020) Multilevel proteomics reveals host perturbations by SARS-CoV-2 and SARS-CoV. Nature 594(7862):246-252. https://doi.org/10.1038/s41586-021-03493-4

Tang Y, Liu J, Zhang D, Xu Z, Ji J, Wen C (2020) Cytokine storm in COVID-19: the current evidence and treatment strategies. Front Immunol 11:1708. https://doi.org/10.3389/fimmu.2020.01708

Totura AL, Baric RS (2012) SARS coronavirus pathogenesis: host innate immune responses and viral antagonism of interferon. Curr Opin Virol 2(3):264-275. https://doi.org/10.1016/j.coviro. 2012.04.004

Tung HYL, Limtung P (2020) Mutations in the phosphorylation sites of SARS-CoV-2 encoded nucleocapsid protein and structure model of sequestration by protein 14-3-3. Biochem Biophys Res Commun 532(1):134-138

Vaduganathan M, Vardeny O, Michel T, McMurray JJV, Pfeffer MA, Solomon SD (2020) Renin-angiotensin-aldosterone system inhibitors in patients with Covid-19. N Engl J Med 382(17):1653-1659. https://doi.org/10.1056/NEJMsr2005760

Walls AC, Park YJ, Tortorici MA, Wall A, McGuire AT, Veesler D (2020) Structure, function, and antigenicity of the SARS-CoV-2 spike glycoprotein. Cell 181(2):281-292 e6

Wu C, Chen X, Cai Y, Xia J, Zhou X, Xu S, Huang H, Zhang L, Du C, Zhang Y, Song J, Wang S, Chao Y, Yang Z, Xu J, Chen D, Xiong W, Xu L, Zhou F, Jiang J, Bai C, Zheng J, Song Y (2020) Risk factors associated with acute respiratory distress syndrome and death in patients with coronavirus disease 2019 pneumonia in wuhan, China. JAMA Intern Med 180(7):934-943. https:// doi.org/10.1001/jamainternmed.2020.0994

Yan R, Zhang Y, Li Y, Xia L, Guo Y, Zhou Q (2020) Structural basis for the recognition of SARS-CoV-2 by full-length human ACE2. Science 367(6485):1444-1448. https://doi.org/10.1126/ science.abb2762

Ye Q, Wang B, Mao J (2020) The pathogenesis and treatment of the 'Cytokine Storm' in COVID-19. J Infect 80(6):607-613

Yi C, Yi Y, Li J (2020) mRNA Vaccines: possible tools to combat SARS-CoV-2. Virol Sin 35(3):259-262. https://doi.org/10.1007/ s12250-020-00243-0 
Zhang H, Penninger JM, Li Y, Zhong N, Slutsky AS (2020a) Angiotensin-converting enzyme 2 (ACE2) as a SARS-CoV-2 receptor: molecular mechanisms and potential therapeutic target. Intensive Care Med 46(4):586-590. https://doi.org/10.1007/ s00134-020-05985-9

Zhang JJ, Dong X, Cao YY, Yuan YD, Yang YB, Yan YQ, Akdis CA, Gao YD (2020b) Clinical characteristics of 140 patients infected with SARS-CoV-2 in Wuhan, China. Allergy 75(7):1730-1741. https://doi.org/10.1111/all.14238
Zheng J (2020) SARS-CoV-2: an emerging coronavirus that causes a global threat. Int J Biol Sci 16(10):1678-1685. https://doi.org/ $10.7150 /$ ijbs. 45053

Publisher's Note Springer Nature remains neutral with regard to jurisdictional claims in published maps and institutional affiliations. 